\title{
PERANAN FILSAFAT ILMU BAGI PERKEMBANGAN ILMU PENGETAHUAN
}

\author{
Oleh: M. Nafiur Rofiq \\ Dosen tetap Institut Agama Islam Al-Falah as-Sunniyyah
}

\begin{abstract}
Abstrak:
Filsafat ilmu merupakan cabang ilmu filsafat yang lahir sekitar akhir abad ke-19 atau menjelang abad ke-20. Perkembangan ilmu pengetahuan yang mencapai puncaknya pada abad ke-19 di masa August Comte dan para penerusnya, yang cenderung menjadikan ukuran kebenaran ilmu pada tataran positivistik, menjadikan ilmu pengetahuan semakin terlepas dari asumsi dasar filsafatnya. Hal inilah yang mengilhami lahirnya filsafat ilmu yang pada gilirannya mempunyai posisi yang amat urgen (penting) dalam ilmu pengetahuan. Urgensi filsafat ilmu dapat dilihat dari peranannya sebagai mitra dialog yang kritis terhadap perkembangan ilmu pengetahuan. Filsafat ilmu juga mencoba memperkenalkan diskursus ilmu pengetahuan secara utuh-integral-integratif. Filsafat ilmu juga menegaskan nilai moral-aksiologis bagi perkembangan ilmu pengetahuan, dan masih banyak lagi. Pada intinya, filsafat ilmu dapat berdiri di tengah-tengah cabang ilmu pengetahuan sebagai pengontrol dan pengarah bagi penerapannya.
\end{abstract}

Kata Kunci: Filsafat Ilmu dan Ilmu Pengetahuan

\section{A. Pendahuluan}

Semenjak masa Renaissance yang disusul dengan Aufklaerung (abad XVIII), filsafat sebagai "induk" cabang-cabang ilmu pengetahuan ditinggalkan oleh "anakanaknya" (cabang-cabang ilmu pengetahuan). Cabang-cabang ilmu pengetahuan bersama "anak kandungnya" (teknologi) cenderung berdiri secara mandiri. Dalam perjalanannya kemudian, ilmu pengetahuan dan teknologi (iptek) mengalami kemajuan sangat pesat dan menghasilkan temuan-temuan spektakuler, sehingga berdampak luas terhadap peradaban hidup manusia.

Ada kecenderungan, bahwa ilmu pengetahuan dipelajari dan diterapkan terlepas dari asumsi-asumsi dasar filsafatnya. Berbagai permasalahan yang timbul -baik teoritis maupun praktis- ditinjau dari sudut pandang masing-masing disiplin ilmu dan diterjemahkan dengan bahasa teknisnya sendiri-sendiri. Akibatnya komunikasi antar ilmu pengetahuan sulit dikembangkan. ${ }^{1}$

Lebih dari itu, perkembangan ilmu pengetahuan amat mempengaruhi kehidupan dan perlu mendapat perhatian, karena bisa berdampak pada perilaku anti-kemanusiaan atau mengganggu keseimbangan antar individu dan masyarakat serta lingkungannya. Misalnya, eksploitasi alam, komersialisasi ilmu, penerapan iptek yang merusak, dls. Dari sini,

1 Koento Wibisono, Pengertian tentang Filsafat, Hand Out, (Yogyakarta: Program Pascasarjana Filsafat UGM, 2005a), 1. 
menurut T. Jacob, ${ }^{2}$ perlu adanya etika ilmiah dalam semua bidang disiplin ilmu pengetahuan.

Bersamaan dengan berbagai permasalahan yang timbul akibat kemajuan iptek dan adanya spesialisasi di semua disiplin ilmu yang berkembang secara mandiri, ilmu pengetahuan kehilangan sifatnya yang utuh-integral-integratif; masing-masing menjadi terisolasi. Terasa adanya kebutuhan saling "menyapa" antar sesama ilmu pengetahuan, sehingga upaya untuk membangun suatu academic community dalam arti kata yang sebenarnya menjadi amat diperlukan.

Menurut Koento Wibisono, ${ }^{3}$ sudah tiba saatnya untuk menyediakan suatu "overview" sebagai jaringan untuk menunjukkan keterkaitan antar sesama cabang ilmu pengetahuan, sehingga ilmu pengetahuan beserta kebenaran ilmiah yang ingin dicapainya tidak dipandang sebagai "barang jadi yang sudah selesai"; mandeg dalam kebekuan dogmatis-formalistik. Visi dan orientasi bahwa ilmu pengetahuan adalah suatu "pengembaraan yang tidak pernah mengenal titik-henti" - a never ending process- harus disadari oleh semua pihak.

Dari uraian tersebut di atas, bahwa perkembangan ilmu pengetahuan yang tidak hanya berimplikasi secara positif tetapi juga negatif, maka dibutuhkan sarana kritik dan mitra dialog yang dapat dipertanggungjawabkan bagi perkembangan ilmu pengetahuan. Adanya kebutuhan untuk saling merekatkan hubungan antar berbagai disiplin ilmu agar bisa saling "menyapa" juga menjadi penting. Untuk menjawab kebutuhan tersebut, filsafat ilmu dianggap mampu menjadi mediasi antar berbagai cabang ilmu pengetahuan agar bisa saling "menyapa". Filsafat ilmu dapat mendemonstrasikan ilmu pengetahuan secara utuhintegral-integratif. Filsafat ilmu bisa sebagai mitra dialog yang kritis bagi perkembangan ilmu pengetahuan. Dengan demikian, menjadi amat penting untuk mengangkat tema "Peranan Filsafat Ilmu bagi Perkembangan Ilmu Pengetahuan".

\section{B. Sekedar Mengenal Filsafat Ilmu}

Berbicara tentang filsafat ilmu, perlu diajukan suatu pertanyaan pada diri sendiri, sejauh mana cabang filsafat ini mempunyai makna dan relevansi dengan masalah-masalah praktis yang urgen dan mendesak, yang menuntut penyelesaian secara praktis, seperti, masalah lapangan kerja bagi lulusan perguruan tinggi, semakin terbatasnya dana dan fasilitas pendidikan, dls. Seiring dengan itu ada satu anggapan bahwa kehadiran filsafat ilmu ini terlalu dini di satu pihak, namun juga dianggap terlambat di pihak lain.

Masih terlalu dini karena oleh sementara kalangan dianggap sebagai suatu kemewahan, non-ekonomis, membuang-buang waktu, sulit dimengerti, tidak pragmatis; namun juga sudah agak terlambat karena semakin terasa adanya berbagai masalah fundamental yang membutuhkan landasan pemikiran yang mendasar dalam

\footnotetext{
${ }^{2}$ T. Jacob, "Etika Ilmiah dan Pancasila", dalam Soeroso H.P., dkk., Pancasila sebagai
} Orientasi Pengembangan Ilmu, (Yogyakarta: Kedaulatan Rakyat), 56-58.

${ }^{3}$ Koento Wibisono, Pengertian tentang Filsafat, 1 
menanggulanginya, seperti, masalah kebebasan mimbar dan akademik, peningkatan mutu pendidikan yang kurang jelas ukurannya, $\mathrm{dll}^{4}$

\section{Ilmu Filsafat dan Filsafat Ilmu (Barat)}

a. Ilmu Filsafat

Secara historis ilmu filsafat berbeda dengan filsafat ilmu. Ilmu filsafat berarti filsafat sebagai cabang ilmu, sedangkan filsafat ilmu berarti filsafat mewarnai seluruh disiplin keilmuan. Filsafat sebagai ilmu tidak jauh beda dengan cabang-cabang ilmu pengetahuan yang lain. Dalam artian memiliki sistematika sebagai berikut: 1) Gegenstand, yaitu suatu objek sasaran untuk diteliti dan diketahui menuju suatu pengetahuan, kenyataan, atau kebenaran. 2) Gegenstand tadi terus menerus dipertanyakan tanpa mengenal titik henti. 3) Setelah itu ada alasan atau motif tertentu, dan dengan cara tertentu mengapa Gegenstand tadi terus-menerus dipertanyakan. 4) Rangkaian dari jawaban yang dikemukakan kemudian disusun kembali ke dalam satu kesatuan sistem. ${ }^{5}$

Menurut Koento Wibisono, ${ }^{6}$ ilmu filsafat adalah ilmu yang menunjukkan bagaimana upaya manusia yang tidak pernah menyerah untuk menentukan kebenaran atau kenyataan secara kritis, mendasar, dan integral. Oleh karena itu dalam filsafat, proses yang dilalui adalah refleksi, kontemplasi, abstraksi, dialog, dan evaluasi menuju suatu sintesis. Ilmu filsafat (filsafat sebagai ilmu) mempertanyakan hakikat (substansi) atau "apanya" dari objek sasaran yang dihadapinya dengan menempatkan objek itu pada kedudukannya secara utuh. Hal ini berbeda dengan ilmu-ilmu cabang yang lain, yang hanya melihat pada satu sisi atau dimensi saja.

Ilmu filsafat dalam menghadapi objek material manusia, yang ingin dicari ialah apa hakikat manusia itu, apa makna kehadirannya serta tujuan hidup baik dalam arti imanen maupun transenden. Dengan melihat objek material manusia hanya pada satu sisi atau dimensi saja, ilmu-ilmu cabang tumbuh menjadi ilmu sosiologi, antropologi, hukum, ekonomi, politik, psikologi, dan lain sebagainya. ${ }^{7}$

\section{b. Filsafat Ilmu (Barat)}

Di zaman modern, terasa adanya kekaburan mengenai batas-batas antara (cabang) ilmu yang satu dengan yang lain, sehingga interdependensi dan inter-relasi ilmu menjadi semakin terasa dibutuhkan. Atau justru yang terjadi sebaliknya, antara ilmu pengetahuan yang satu dengan yang lain saling terpisah secara dikotomis tanpa adanya kemauan untuk saling "menyapa".

Oleh karena itu diperlukan "overview" untuk meletakkan jaringan interaksi agar berbagai disiplin ilmu bisa "saling menyapa" menuju hakikat ilmu yang integral dan integratif. Kehadiran etik dan moral menjadi semakin dirasakan pentingnya. Sikap pandang

\footnotetext{
${ }^{4}$ Ibid, 3

${ }^{5}$ Ibid

${ }^{6} \mathrm{Ibid}, 5$.

${ }^{7}$ Ibid, 4.
} 
bahwa "ilmu adalah bebas nilai" semakin ditinggalkan. Tanggung jawab dan integritas seorang ilmuwan kini sedang diuji. ${ }^{8}$

Dalam perjalanannya kemudian, timbul kebutuhan untuk mengembangkan filsafat ilmu (philosophy of science), yang memang amat penting dalam memberikan nilai atau aksiologi terhadap perkembangan dan kemajuan ilmu pengetahuan dan teknologi ${ }^{9}$ disamping juga penting untuk memberikan batas-batas keilmuan agar tidak kabur. Akhirakhir ini filsafat ilmu (ilmunya ilmu) juga digalakkan di kalangan beberapa perguruan tinggi atau program studi demi menghadapi implikasi-implikasi -baik positif maupun negatif- perkembangan ilmu pengetahuan bagi kehidupan umat manusia.

Filsafat (ilmu -pen.) sebagai ilmu kritis, ${ }^{10}$ diharapkan ikut berperan sebagai dasar dan arah dalam penyelesaian masalah-masalah fundamental di bidang sosial, ideologi, politik, ekonomi, pendidikan, dan lain sebagainya. Selain itu, filsafat ilmu diharapkan mampu menjadi mitra dialog dan sarana kritik terhadap perkembangan ilmu pengetahuan.

Filsafat ilmu merupakan kelanjutan daripada epistemologi. Epistemologi merupakan pengetahuan yang mendasarkan diri pada sumber atau sarana tertentu seperti panca indera, akal (verstand), akal-budi (vernunft) dan intuisi. Dari situ berkembanglah berbagai macam "school of thought", yakni rasionalisme (Descartes), empirisme (John Locke), kritisisme (Immanuel Kant), positivisme (August Comte), fenomenologi (Husserl), eksistensialisme (Sartre) konstruktivisme (Fayerabend), dan seterusnya.

Hakikat ilmu yang merupakan tiang penyangga bagi eksistensi ilmu dan menjadi objek formal filsafat ilmu adalah ontologi, epistemologi, dan aksiologi. ${ }^{11}$ Ontologi ilmu meliputi hakikat ilmu, kebenaran, dan kenyataan yang inheren dengan pengetahuan ilmiah, yang tidak terlepas dari persepsi filsafati tentang apa dan bagaimana (yang) "ada" itu. Faham Monisme yang terpecah menjadi idealisme/spiritualisme, materialisme, dualisme, pluralisme, dengan berbagai nuansanya, merupakan faham ontologik yang pada akhirnya menentukan pendapat bahkan "keyakinan" mengenai apa dan bagaimana (yang) "ada" sebagaimana manifestasi kebenaran yang dicari. ${ }^{12}$

Epistemologi ilmu meliputi sumber, sarana, dan tata-cara menggunakan sarana tersebut untuk mencapai pengetahuan ilmiah. Perbedaan mengenai pilihan landasan

\footnotetext{
${ }^{8}$ Koento Wibisono, "Ilmu Pengetahuan, sebuah Sketsa umum mengenai Kelahiran dan Perkembangannya sebagai Pengantar untuk Memahami Filsafat Ilmu", dalam Koento Wibisono, Hubungan Filsafat, Ilmu Pengetahuan, dan Budaya, Hand Out, (Yogyakarta: Program Pascasarjana Filsafat UGM, 2005b), 10-11.
}

${ }^{9}$ Archie Bahm, J., What is Science, (Albuquerge, New Mexico: World Books, 1980), 36.

${ }^{10}$ Magnis Suseno, Filsafat sebagai Ilmu Kritis, (Yogyakarta: Kanisius, 1992).

${ }^{11}$ Jujun S. Suriasumantri, Filsafat Ilmu, (Jakarta: Sinar Harapan, 1984).

${ }^{12}$ Lihat Koento Wibisono, "Ilmu Pengetahuan, sebuah Sketsa umum mengenai Kelahiran dan Perkembangannya sebagai Pengantar untuk Memahami Filsafat Ilmu", dalam Koento Wibisono, Hubungan Filsafat, Ilmu Pengetahuan, dan Budaya, 12-13. 
ontologik akan dengan sendirinya mengakibatkan perbedaan dalam menentukan sarana yang akan dipilih. Akal (verstand), akal budi (vernunft), pengalaman, atau kombinasi antara akal dan pengalaman, intuisi, merupakan sarana yang dimaksud dalam epistemologi, sehingga dikenal adanya model-model epistemologi seperti rasionalisme, empirisme, kritisisme atau rasionalisme kritis, positivisme, fenomenologi, eksistensialisme, konstruktivisme, dls.

Aksiologi ilmu meliputi nilai-nilai (values) yang bersifat normatif dalam pemberian makna terhadap kebenaran atau keyataan sebagaimana dijumpai dalam kehidupan yang menjelajahi berbagai kawasan, seperti, kawasan sosial, simbolik, atau fisik-material. Lebih Dari itu nilai-nilai juga ditunjukkan oleh aksiologi sebagai suatu "condition sine quanon" yang wajib dipatuhi dalam kegiatan manusia, baik dalam melakukan penelitian maupun dalam penerapan ilmu. Sementara itu objek material dari filsafat ilmu adalah segala ilmu pengetahuan.

\section{Filsafat Ilmu (Islam)}

Filsafat ilmu dalam Islam mengenal tiga aliran besar; bayani (telaah teks), irfani (rasio-intuisi), dan burhani (empiri). Paradigma filsafat ilmu Islam merentang dari empirik-sensual, empirik-logik, empirik-etik, dan empirik-transendental. Filsafat ilmu Barat tidak menyentuh dataran empirik-transendental. ${ }^{13}$

Kawasan ilmu dalam Islam, oleh Noeng Muhadjir disebut dengan non-tasyri' atau cum scientific (dalam bahasa Mukti Ali). Hal ini meliputi tajdid dan ijtihad atau usaha pembaharuan. Ini bisa berupa pembuatan telaah secara baik dalam wujud tafsir atau ta'wil dari wahyu pada persoalan yang bisa dijangkau akal; bukan persoalan yang ghaib seperti dzat Allah, ${ }^{14}$ sebab itu adalah urusan Allah, dan akal tidak akan dapat mencapai pemahaman yang baik, bahkan bisa mengarah pada kesesatan. Dalam bahasa Amin Abdullah, ${ }^{15}$ kawasan ilmu dalam Islam disebut dengan historisitas.

Dalam perkembangannya, filsafat ilmu irfani menjurus dalam aksentuasi yang beragam. Irfani yang lebih menekankan intuisi berkembang ke ilmu kalam dengan telaah dialektik addalaalah (dalil-dalil), yang akhirnya menolak telaah filsafat. Irfani yang dikembangkan dalam fiqh mengarah ke telaah dialektika al-'illah (argumentasi); mendialektikakan antara kata dan makna. Irfani dalam tafsir mengarah ke epistemologi lughawiyah (bahasa); membuat telaah tekstual dan menggunakan logika koherensi. Filsafat ilmu bayani menjadi aliran dominan dalam ulumiddin (ilmu-ilmu agama). Irfani

13 Noeng Muhadjir, Filsafat Islam Telaah Fungsional, Suplemen Filsafat Ilmu edisi II, (Yogyakarta: Rake Sarasin, 2003), 1.

${ }^{14}$ Lihat al-Qur'an al-Karim; lihat juga dalam Noeng Muhadjir, Ibid

15 Amin Abdullah, Studi Agama: Normativitas atau Historisitas, cet 2, (Yogyakarta: Pustaka Pelajar, 1999) 
berkembang secara beragam dan juga dominan dalam ulumiddin. Sementara burhani tidak begitu punya tempat untuk berkembang dalam ulumiddin. ${ }^{16}$

Filsafat ilmu Barat menempatkan empiri sebagai sarana yang dominan. Rasio perlu tunduk pada bukti empiri. Pada zaman Rasulullah Saw. banyak empiri menjadi landasan keputusan Rasul. Ketika Rasul menawarkan strategi perangnya, ada sahabat yang bertanya, apakah itu wahyu atau pendapat Rasul? Oleh karena itu pendapat Rasul maka Rasul menerima strategi yang ditawarkan oleh sahabat. ${ }^{17}$

Dikatakan bahwa Yunani merupakan induknya ilmu murni, sedangkan Islam adalah induk teknologi. Mengapa umat Islam sekarang memusuhi teknologi? Memang iptek dahulu adalah teistik, sedang iptek sekarang sekuler. Tugas ilmuwan muslim adalah mengembalikan iptek menjadi teistik. Filsafat paripatetik (diskusi jalan-jalan) Yunani telah ditradisikan dalam filsafat Islam Andalusia, yang corak kerjanya dengan metode eksperimental dengan pembuktian logika matematik-korespondensi. Dapat dibayangkan bagaimana rumitnya matematika bila menggunakan angka lain selain Arab (0). Arti angka 0 memecahkan arti filsafat spekulatif Yunani; tidak ada yang ada. ${ }^{18}$

Dengan demikian jalur tradisi keilmuan iptek sekarang adalah Yunani sebagai induk ilmu yang lebih konseptual teoritik. Sementara iptek yang sekarang berkembang dalam integrasi rasionalitas dengan pencermatan empirik-eksperimental telah dirintis ilmuwan Islam Andalusia. Persoalannya, mengapa Islam tertinggal saat ini? Umat Islam telah memilih menyelamatkan hidup di akhirat dan meninggalkan dunia. Padahal Allah telah menjanjikan bahwa hidup di dunia memberikan kebaikan bagi yang beriman dan yang tidak beriman. Kehidupan akhirat memberikan kebahagiaan bagi yang beriman.

\section{Sekilas tentang Ilmu Pengetahuan}

\section{Memahami Substansi Ilmu Pengetahuan}

Ilmu pengetahuan merupakan pengetahuan yang dapat diandalkan, sebab tubuh pengetahuannya bukan saja mempunyai kerangka pemikiran yang logis melainkan juga telah teruji. Ilmu pengetahuan merupakan produk dari proses berfikir, meski tidak semua kegiatan berfikir dapat digolongkan dalam pengetahuan ilmiah. Umpamanya saja lamunan, ini merupakan berfikir rasional tetapi tidak ilmiah karena tidak sistematis. ${ }^{19}$

Menurut T. Jacob ${ }^{20}$ ilmu pengetahuan merupakan suatu sistem yang dikembangkan manusia mengenai hidup dan lingkungannya, menyesuaikan diri dengan lingkungannya, serta menyesuaikan lingkungan dengan dirinya dalam rangka strategi pengembangan

16 Noeng Muhadjir, 1

17 Telusuri di al-Hadits al-Nabawi; lihat juga dalam Noeng Muhadjir,

18 Noeng Muhadjir, Ibid, 17-18.

19 Jujun S. Suriasumantri, Ilmu dalam Perspektif Moral, Sosial, dan Politik: Sebuah Dialog tentang Dunia Keilmuan Dewasa Ini, (Jakarta: PT. Gramedia, 1986), 19.

${ }^{20}$ T. Jacob, Manusia, Ilmu dan Teknologi, Pergumulan Abadi dalam Perang dan Damai, (Yogyakarta: PT. Tiara Wacana, 1988), 7-8. 
hidupnya. Sementara itu teknologi merupakan konsekwensi lebih lanjut yang merupakan penerapan daripada ilmu, baik modern maupun folk-science.

Daoed Joesoef ${ }^{21}$ menambahkan bahwa ilmu pengetahuan adalah penerapan yang selogis mungkin dari nalar manusia. Nalar manusia di mana pun sama tetapi penerapannya berbeda. Bila sistem nilai berbeda antara masyarakat yang satu dengan yang lain, maka pengetahuan ilmiah dan mentalitas teknologi berbeda menurut tingkat kemajuan masyarakat yang bersangkutan. Untuk itu diperlukan pembentukan ilmu pengetahuan yang tidak hanya sebagai produk tetapi lebih sebagai proses.

Tujuan ilmu pengetahuan adalah mencari penjelasan dari gejala-gejala yang ditemukan, yang memungkinkan untuk mengetahui sepenuhnya akan hakikat objek yang dihadapi. Pengetahuan itu memungkinkan manusia untuk mengerti dan memberikan alat untuk menguasai suatu masalah. Hal ini berlaku bagi ilmu-ilmu alam maupun sosial. ${ }^{22}$ Meski demikian, dengan ilmu pengetahuan manusia tidak mutlak mengetahui segalanya, pengetahuan manusia tetap dalam koridor keterbatasan.

Keterbatasan akan penguasaan ilmu pengetahuan mengingatkan kepada manusia bahwa ada sesuatu yang lebih tinggi darinya, yang mana akal manusia tidak mampu menjangkaunya. Orang yang mengekor pada ilmu pengetahuan secara membabi buta, akan terbentur pada satu permasalahan yang ia sendiri tidak mampu melampauinya. Dengan memahami hal ini maka manusia bisa merenung bahwa sebenarnya hal itu sudah diingatkan oleh sila I dari lima sila negara Indonesia, yakni 'Ketuhanan Yang Maha Esa”.

Daoed Joesoef ${ }^{23}$ melihat, bahwa dalam arti yang lengkap, ilmu pengetahuan mempunyai makna sebagai produk, proses, dan masyarakat. Ilmu pengetahuan sebagai produk maksudnya, pengetahuan yang telah diakui kebenarannya oleh masyarakat ilmuwan. Dari sini ilmu pengetahuan mengandung kemungkina untuk disepakati dan terbuka untuk diteliti, diuji atau dibantah orang lain. Oleh karena itu tidak mungkin suatu fakta ilmiah itu bersifat original, yang original adalah penemuan dari fakta ilmiah itu sendiri, sehingga timing dari suatu penemuan atau publikasi menjadi penting di sini.

Ilmu pengetahuan sebagai proses maksudnya, kegiatan masyarakat yang dilakukan demi penemuan dan pemahaman dunia alami sebagaimana adanya dan bukan sebagaimana yang direkayasa/dimanipulasi. Metode ilmiah yang khas dipakai dalam proses ini adalah analisis rasional, objektif, sejauh mungkin bersifat impersonal, dari masalah-masalah yang dihadapi atau diamati. Bagi Thomas S. Kuhn, normal science adalah ilmu pengetahuan dalam artian proses (penelitian).

Ilmu pengetahuan sebagai masyarakat maksudnya, dunia pergaulan yang perilakunya diatur oleh empat ketentuan (imperatif), yaitu universalisme, komunalisme,

${ }^{21}$ Daoed Joesoef, Pancasila, Kebudayaan, dan ilmu Pengetahuan, Pidato Kunci pada Seminar Nasional: "Pancasila sebagai Orientasi Pengembangan Ilmu", (Yogyakarta: Fakultas Filsafat UGM, 1986), 36.

22 Jujun S. Suriasumantri, Ilmu dalam Perspektif Moral, Sosial, dan Politik: Sebuah Dialog tentang Dunia Keilmuan Dewasa Ini, 95.

${ }^{23}$ Ibid, 25-26 
tanpa pamrih, dan skeptisisme yang teratur. Universalisme berarti ilmu pengetahuan bebas dari warna kulit, ras, keturunan, maupun keyakinan keagamaan. Universal artinya ilmu pengetahuan bisa dipakai di tempat mana pun. Universalisme bukan dalam arti disiplin ilmunya, sebab disiplin ilmu bersifat plural sesuai dengan metode dan struktur yang mendasarinya. Komunalisme berarti ilmu pengetahuan merupakan milik masyarakat (public knowledge). Tanpa pamrih berarti ilmu pengetahuan bukan propaganda untuk maksud-maksud busuk tertentu. Skeptisisme yang teratur berarti keinginan untuk mengetahui dan bertanya didasarkan pada nalar dan sistematika berfikir.

Kenyataan telah menunjukkan bahwa kedudukan ilmu pengetahuan secara substantif (dan bukan hanya sekedar sarana dalam kehidupan umat manusia) telah menyentuh semua sendi dan segi kehidupan, dan pada gilirannya akan mengubah budaya manusia secara intensif. ${ }^{24}$ Tidak ada yang bisa membantah ungkapan; bahwa perkembangan ilmu pengetahuan telah mewarnai dunia secara dominan.

\section{Ilmu Pengetahuan Mencapai Puncaknya di era Modern}

Perkembangan ilmu pengetahuan dan juga ilmu sosial dengan pendekatan empiris, mencapai bentuknya secara definitif dengan kehadiran Auguste Comte (1798-1857) dengan grand-theori-nya yang digelar dalam karyanya Cours de Philosophie Positive yang mengajarkan bahwa cara berfikir manusia, juga masyarakat di mana pun akan mencapai puncaknya pada tahap positif, setelah melalui tahap theologik dan metafisik. Istilah positif olehnya diberi arti eksplisit dengan muatan filsafati, yaitu menerangkan bahwa yang benar dan yang nyata haruslah konkret, eksak, akurat, dan memberi kemanfaatan. ${ }^{25}$

Metode observasi, eksperimentasi, dan komparasi yang dipelopori Francis Bacon (1561-1626) juga ikut mendorong pesatnya perkembangan ilmu pengetahuan, dimana para ilmuwan setelahnya seperti Helmholtz, Pasteur, Darwin, Clerk Maxwell, berhasil menemukan hal-hal yang baru dalam penelitian ilmiahnya. Kesemuanya itu memberi isyarat bahwa dunia Barat telah berhasil melakukan tinggal landas untuk mengarungi dirgantara ilmu pengetahuan yang tiada bertepi.

Battle Cry-nya Francis Bacon yang menyerukan bahwa "knowledge is power" bukan sekedar mitos, melainkan sudah menjadi etos. Hal itu telah melahirkan corak dan sikap pandang manusia yang meyakini kemampuan rasionalitasnya untuk menguasai dan meramalkan masa depan, dan dengan optimismenya, berinovasi secara kreatif untuk membuka rahasia-rahasia alam. Semenjak itu masyarakat Barat menjadi masyarakat yang tiada hari tanpa temuan-temuan baru yang muncul secara historis, kronologis, berurutan, dan berdampingan sebagai alternatif.

"Revolusi" ilmu pengetahuan telah berlanjut di abad ke-20 berkat teori relativitasnya Einstein yang telah merombak filsafat Newton yang semula dianggap sudah mapan, disamping teori kuantumnya yang telah mengubah persepsi dunia ilmu

\footnotetext{
${ }^{24}$ Koento Wibisono, "Ilmu Pengetahuan, sebuah Sketsa umum mengenai Kelahiran dan Perkembangannya sebagai Pengantar untuk Memahami Filsafat Ilmu", dalam Koento Wibisono, Hubungan Filsafat, Ilmu Pengetahuan, dan Budaya, 8.

${ }^{25}$ Ibid, 6.
} 
pengetahuan tentang sifat-sifat dasar dan perilaku materi sedemikian rupa sehingga para pakar dapat melanjutkan penelitian-penelitiannya, dan berhasil mengembangkan ilmu-ilmu dasar seperti astronomi, fisika, kimia, biologi molekuler, sebagaimana hasilnya dapat “dinikmati” oleh manusia di abad ke-21 sekarang ini.

Dalam menghadapi perkembangan ilmu pengetahuan dengan temuan-temuan spektakulernya, rasa optimisme -disamping pesimisme- merupakan sikap manusia masa kini yang di satu pihak telah meningkatkan fasilitas hidup, yang berarti menambah kenikmatan; namun di pihak lain gejala-gejala adanya dekadensi moral kemanusiaan menjadi semakin meningkat dengan akibat-akibat yang cukup fatal.

Secara historis, pergulatan besar sumber pengetahuan yang menunjang kemajuan ilmu pengetahuan di era sekarang, dimulai dari Rasionalisme dengan tokohnya Rene Descartes, Empirisme dengan tokohnya John Locke, dan kritisisme dengan tokohnya Immanuel Kant. Pergulatan tersebut kemudian berpuncak pada pemikiran August Comte dengan aliran Positivisme-nya. Abad ke-19 bisa dikatakan sebagai abad Positivisme karena begitu kuat dan luasnya pengaruh aliran ini di abad modern. Ukuran kebenaran dinilai dari sudut positivistik-nya. Filsafat menjadi praktis bagi tingkah laku perbuatan manusia sehingga tidak lagi memandang penting berfikir abstrak. ${ }^{26}$

\section{Peranan Filsafat Ilmu bagi Perkembangan Ilmu Pengetahuan}

Pertumbuhan dan perkembangan iptek secara mendasar, menyeluruh, dan cepat telah dirasakan oleh umat manusia secara ambivalen, artinya kadang berdampak positif dan kadang negatif. Van Peursen ${ }^{27}$ telah melihat hal itu, sehingga ia menawarkan adanya hubungan antara pengetahuan dan perbuatan; ilmu pengetahuan dan etika. Hubungan ini merupakan keharusan dan urutannya menjadi ilmu pengetahuan, teknik, dan etika.

Situasi dan kondisi sekarang berbeda dengan situasi dan kondisi masa silam. Dalam situasi saat ini, iptek telah menguasai kehidupan umat manusia. Meski demikian, cara hidup kurang dilandasi dengan suatu perangkat yang jelas dan mapan, dan hal itu sudah tidak mungkin dipertahankan jika tidak ingin menjadi budaknya ilmu pengetahuan dan teknologi itu sendiri, dan jika tidak ingin menjadi orang yang bermasa depan tanpa arah. ${ }^{28}$

Penguasaan ilmu secara canggih dengan kemampuan prediktifnya akan membantu manusia dalam mengelola kehidupan untuk meraih citra masa depan. Sesuatu yang dipertaruhkan adalah masa depan para generasi penerus yang pada saatnya harus siap melanjutkan kepemimpinan yang arif dalam mengelola kehidupan sebagai suatu bangsa yang besar dan terhormat.

26 Koento Wibisono, Arti Perkembangan menurut Positivisme August Comte, cet 2, (Yogyakarta: Gadjah Mada University Press, 1996), 1.

${ }^{27}$ Van Peursen, Strategi Kebudayaan, terj. Dick Hartoko, (Yogyakarta: Kanisius, \& BPK Gunung Mulia, Jakarta, 1976), 179-180.

${ }^{28}$ Koento Wibisono, "Ilmu Pengetahuan, sebuah Sketsa umum mengenai Kelahiran dan Perkembangannya sebagai Pengantar untuk Memahami Filsafat Ilmu", dalam Koento Wibisono, Hubungan Filsafat, Ilmu Pengetahuan, dan Budaya, 13. 
Dari situ, diperlukan sarana untuk membuat sang ilmuwan menjadi arif dan bijaksana. Diperlukan juga adanya sesuatu yang mendasari perkembangan ilmu pengetahuan dan teknologi agar kehadirannya lebih banyak berimplikasi positif daripada negatifnya. Menurut beberapa pakar, bahwa yang bisa menjadikan tonggak aksiologis dalam mengarahkan perkembangan iptek secara positif untuk kepentingan umat manusia dan lingkungannya adalah filsafat ilmu (ilmu tentang ilmu).

\section{Dilema dan Strategi Pengembangan Ilmu Pengetahuan}

Kini ilmu telah menjelajahi lingkup yang amat luas dan mendalam, hingga menyentuh sendi-sendi kehidupan umat manusia yang paling dasariah, baik secara individu maupun sosial. Implikasi yang kini dirasakan ialah: Pertama, ilmu yang satu sangat berkaitan dengan ilmu yang lain sehingga sulit ditarik batas antara ilmu dasar dan ilmu terapan; antara teori dan praktis. Kedua, dengan semakin kaburnya batas tadi, timbul permasalahan, sejauh mana sang ilmuwan terlibat dengan etik dan moral. Ketiga, dengan adanya implikasi yang begitu luas dan dalam terhadap kehidupan umat manusia, timbul pula permasalahan akan makna ilmu itu sendiri sebagai sesuatu yang membawa kemajuan atau malah sebaliknya. ${ }^{29}$

Sementara itu, di satu sisi timbul gagasan ideal untuk mengembangkan perguruan tingi menjadi suatu lembaga penelitian yang canggih sebagaimana sering dikemukakan oleh berbagai pihak bahwa sudah tiba saatnya untuk mengarahkan suatu universitas menjadi "research university". Di sisi lain sikap pandang "pragmatisme" dan "target oriented" juga mulai merebak di berbagai perguruan tinggi dengan munculnya pendirian berbagai macam program exstension dan program diploma serta program magister yang diarahkan untuk "meningkatkan kualitas suatu profesi" tertentu. Implikasi yang timbul, menurut Koento Wibisono, ${ }^{30}$ ialah bahwa keterampilan untuk memenuhi kebutuhan pasaran tenaga kerja dibekalkan tanpa disertai wawasan ilmiah yang dibutuhkan bagi penerapan suatu profesi. Etik dan moral akademik menjadi sering terabaikan; sepi dari perhatian.

Bagaimanapun, ilmu pengetahuan harus tetap dikembangkan dengan beragam strateginya. Mengenai strategi pengembangan ilmu, dewasa ini terdapat adanya tiga macam pendapat. Pertama, pendapat yang menyatakan bahwa ilmu berkembang secara otonom dan tertutup, dalam arti pengaruh konteks dibatasi atau bahkan disingkirkan. "Science for the sake of science only" merupakan semboyan yang didengungkan. ${ }^{31}$

29 Koento Wibisono, Ilmu Filsafat dan Aktualitasnya dalam Pembangunan Nasional: Suatu Tinjauan dari Sudut Tradisi Pemikiran Barat, (Yogyakarta: Gadjah Mada University Press, 1985), 5-6.

${ }^{30}$ Koento Wibisono, Pengertian tentang Filsafat, 1.

${ }^{31}$ Koento Wibisono, "Ilmu Pengetahuan, sebuah Sketsa umum mengenai Kelahiran dan Perkembangannya sebagai Pengantar untuk Memahami Filsafat Ilmu", dalam Koento Wibisono, Hubungan Filsafat, Ilmu Pengetahuan, dan Budaya, 13. 
Kedua, pendapat yang menyatakan bahwa ilmu lebur dalam konteks, tidak hanya memberikan refleksi, tetapi juga memberikan justifikasi. Dengan ini ilmu cenderung memasuki kawasan untuk menjadikan dirinya sebagai ideolog. Ketiga, pendapat yang menyatakan bahwa ilmu dan konteks saling meresapi dan saling memberi pengaruh untuk menjaga dirinya beserta temuan-temuannya agar tidak terjebak dalam kemiskinan relevansi dan aktualisasinya. "Science for the sake of human progress" adalah pendiriannya.

Dalam pada itu Koento Wibisono ${ }^{32}$ melanjutkan, bahwa sebagaimana adanya dampak pengaruh globalisasi -baik positif maupun negatif- yang tidak dapat dielakkan, maka tidak dapat dihindarkan pula adanya urgensi untuk mengembangkan ilmu (dengan asumsi dasar filsafatnya) tidak hanya atas dasar metodologi yang dibatasi oleh context of justification, melainkan juga atas dasar heuristic (pemahaman baru) yang bergerak dalam context of discovery.

\section{Peranan Filsafat Ilmu}

Dengan menunjukkan sketsa umum (gambaran secara garis besar) mengenai perkembangan ilmu pengetahuan yang pada gilirannya melahirkan suatu cabang filsafat ilmu, kiranya menjadi jelas bahwa filsafat ilmu bukanlah sekedar metode atau tata-cara penulisan karya ilmiah atau pun penelitian. Filsafat ilmu adalah refleksi filsafati yang tidak pernah mengenal titik henti dalam menjelajahi kawasan ilmiah untuk mencapai kebenaran atau kenyataan, sesuatu yang memang tidak pernah akan habis difikirkan dan tidak pernah akan selesai diterangkan. ${ }^{33}$

Ace Partadiredja dalam pidato pengukuhannya selaku guru besar ekonomi di UGM mendambakan ilmu ekonomi yang tidak mengajarkan keserakahan. ${ }^{34}$ Ini merupakan suara segar dalam kemandulan perhatian ilmuwan kepada masalah moral. Terlepas dari semantik kata-kata, yang jelas ungkapan Ace mengajak manusia bahwa di samping cerdas juga harus bermoral luhur. Menurut hematnya, bahwa tujuan pendidikan moral tersebut dapat dicapai dengan peningkatan kekuatan penalaran ilmiah, yakni melalui pemberian materi ajar filsafat ilmu.

Filsafat (ilmu) diharapkan dapat berdiri di tengah-tengah ilmu-ilmu pengetahuan. Di sini bukan berarti filsafat ilmu menjadi semacam puncak ekstasi rasional ilmu-ilmu, mahkota ilmu-ilmu, atau ratu ilmu-ilmu; status simbolis yang boleh diagungkan, meski tak punya tangan untuk berbuat. ${ }^{35}$ Filsafat ilmu (kritis) yang dimaksud di sini adalah memiliki fungsi reflektif dan pragmatis, yaitu menempatkan klaim-klaim analitis ilmu-ilmu

${ }^{32} \mathrm{Ibid}, 14$.

${ }^{33}$ Koento Wibisono, "Ilmu Pengetahuan, sebuah Sketsa umum mengenai Kelahiran dan Perkembangannya sebagai Pengantar untuk Memahami Filsafat Ilmu", dalam Koento Wibisono, Hubungan Filsafat, Ilmu Pengetahuan, dan Budaya, 14.

${ }^{34}$ Kompas, 25 Mei 1981; lihat juga dalam Jujun S. Suriasumantri, Ilmu dalam Perspektif Moral, Sosial, dan Politik: Sebuah Dialog tentang Dunia Keilmuan Dewasa Ini, 13.

${ }^{35}$ Hardiman, Melampaui Positivisme dan Modernitas, (Yogyakarta: Kanisius, 2003), 19. 
pengetahuan dalam rangka proses transformasi abadi masyarakat dan umat manusia. Dengan demikian filsafat ilmu memberikan teoritis-etis bagi ilmu-ilmu pengetahuan dan masyarakat.

Menurut Poespoprojo, ${ }^{36}$ hakikat ilmu adalah persoalan fundamental dan kebenaran universal yang implisit melekat di dalam dirinya. Dengan memahami filsafat ilmu, berarti memahami seluk-beluk ilmu yang paling mendasar, sehingga dapat dipahami pula perspektif ilmu, pengembangannya, keterjalinan antar cabang ilmu yang satu dengan yang lain, serta simplifikasi dan artifisialitasnya.

Itulah sebabnya aktualitas filsafat ilmu semakin terasa. Dengan filsafat ilmu manusia akan semakin dapat memperluas cakrawala wawasan ilmiahnya. Ketajaman refleksi, kedalaman imajinasi, kepekaan intuisi manusia akan terpacu sedemikian rupa sehingga terhindar dari bahaya kerabunan intelektual, simplifisme berfikir yang memuakkan, kehanyutan dalam arus konservatisme ilmu yang timbul karena ilmu dipandang sebagai kata benda (noun) atau barang jadi (taken forgranted) yang sudah selesai, mandeg dan tertutup. ${ }^{37}$

Dengan filsafat ilmu manusia juga akan mampu mensublimasikan disiplin ilmu yang menjadi tanggung jawabnya masing-masing, dan mengangkatnya ke dataran filsafati, sehingga manusia dapat memahami perspektif serta berbagai kemungkinan arah pengembangannya; supaya manusia bisa melakukan spekulasi-spekulasi yang mendalam guna menemukan teori-teori atau paradigma-paradigma baru yang tepat-guna bagi kepentingan umat manusia.

Tanpa kesanggupan itu manusia akan hanya menjadi konsumen ilmu orang lain, membeo, menjadi 'his master's voice'-nya orang lain, itu pun masih dengan kemungkinan adanya distorsi ilmiah, karena lemahnya pemahaman atau penguasaan dalam bahasa asing. Adalah tugas filsafat ilmu di tengah-tengah ilmu-ilmu untuk mengembalikan kecanggihan konseptual yang berlebihan pada pangkalnya yang sederhana namun fundamental, menyingkapkan kaitan klaim objektif dengan matra kekuasaan dan kepentingan, dan pada gilirannya membantu proses pemahaman dan peningkatan diri dan masyarakat. ${ }^{38}$

Dalam perkembangannya filsafat ilmu juga mengarahkan ilmuwan pada strategi pengembangan ilmu, yang menyangkut etik dan heuristik, bahkan sampai pada dimensi kebudayaan untuk menangkap -tidak saja kegunaan atau kemanfaatan ilmu -tetapi juga arti dan maknanya bagi kehidupan umat manusia. Dari situ dapat diketahui, betapa pentingnya kedudukan filsafat ilmu dalam perkembangan ilmu pengetahuan.

${ }^{36}$ Poespoprojo, “Aktualitas Filsafat Ilmu ke Arah Kemasakan Praktek dan Pengelolaan Ilmu", dalam Jujun S. Suriasumantri, Ilmu dalam Perspektif Moral, Sosial, dan Politik, (Jakarta: Gramedia, 1986), 14.

${ }^{37}$ Koento Wibisono, "Ilmu Pengetahuan, sebuah Sketsa umum mengenai Kelahiran dan Perkembangannya sebagai Pengantar untuk Memahami Filsafat Ilmu", dalam Koento Wibisono, Hubungan Filsafat, Ilmu Pengetahuan, dan Budaya, 6.

${ }^{38}$ Hardiman, 20. 


\section{E. Catatan Akhir: Kritik dan Saran mengenai Filsafat Ilmu}

Dari uraian panjang di atas, penulis dan pembaca dapat mengetahui betapa pentingnya kedudukan filsafat ilmu dalam perkembangan ilmu pengetahuan. Filsafat ilmu mampu berperan sebagai mitra dialog yang kritis, penegas nilai moral-aksiologis, dan masih banyak lagi bagi perkembangan ilmu pengetahuan. Meski demikian ada beberapa catatan kritis dan saran mengenai filsafat ilmu di bawah ini.

Dewasa ini filsafat ilmu diberikan secara sporadic pada setiap jenjang pendidikan, khususnya perguruan tinggi. Akan tetapi, materi filsafat ilmu yang diberikan terlalu menekankan aspek penalarannya dan kurang memperhatikan aspek moral keilmuannya. Cara penyampaian yang sukar dan kurang memperhatikan aspirasi atau cara berfikir peserta didik menjadikan filsafat ilmu sebagai objek yang kurang menarik. Sebagai dasar bagi proses pendidikan yang menghasilkan manusia -yang disamping cerdas dan terampil juga bermoral luhur- maka disarankan agar diberikan filsafat ilmu pada semua tingkatan pendidikan dengan tujuan/metode instruksional yang memperhatikan berbagai faktor. ${ }^{39}$

Memasukkan matakuliah filsafat ilmu (dengan berbagai perbaikan di dalamnya) ke dalam kurikulum pendidikan adalah amat tepat, dalam rangka peningkatan mutu akademik, sebab filsafat ilmu berperan dalam meningkatkan mutu pendidikan tinggi dan paradigma 'manusia Indonesia seutuhnya' yang dalam penalarannya diharapkan mampu melakukan terobosan ke kawasan yang paling mendasar untuk memahami hakikat ilmu sampai pada batas yang ultimate.

Poesporodjo, Dosen Universitas Padjadjaran, yang kemudian dikutip oleh Koento Wibisono, ${ }^{40}$ menyatakan bahwa bagi para sarjana, lebih-lebih kandidat doctor, harinya sudah terlalu siang untuk tidak mengetahui hakikat ilmu, posisi ilmu dalam cakrawala pengetahuan manusia, peran ilmu bagi eksistensi manusia. Dengan memahami seluk beluk ilmu secara ilmiah-filsafati, tanpa harus menjadi seorang filsuf, akan menjadikan diri manusia sebagai ilmuwan yang arif, ${ }^{41}$ terhindar dari kecongkakan intelektual yang memuakkan, dan tidak hanyut dalam biduk tradisi yang memandang ilmu sebagai barang jadi, mandeg, dan hanya sebagai hafalan.

39 Jujun S. S., Ilmu dalam Perspektif Moral, Sosial, dan Politik: Sebuah Dialog tentang Dunia Keilmuan Dewasa Ini, 13-14.

${ }^{40}$ Koento Wibisono, "Ilmu Pengetahuan, sebuah Sketsa umum mengenai Kelahiran dan Perkembangannya sebagai Pengantar untuk Memahami Filsafat Ilmu", dalam Koento Wibisono, Hubungan Filsafat, Ilmu Pengetahuan, dan Budaya, 14-15.

41 Bandingkan dengan pandangan Prof. Djohar, Materi Perkuliahan Filsafat Ilmu, (Yogyakarta: PPS UNY, 2007). 


\section{DAFTAR PUSTAKA}

Al-Qur'an al-Karim

Al-Hadits al-Nabawi

Amin Abdullah, 1999, Studi Agama: Normativitas atau Historisitas, cet 2, (Yogyakarta: Pustaka Pelajar).

Bahm, Archie, 1980, What is Science, (Albuquerge, New Mexico: World Books).

Daoed Joesoef, 1986, Pancasila, Kebudayaan, dan ilmu Pengetahuan, Pidato Kunci pada Seminar Nasional: "Pancasila sebagai Orientasi Pengembangan Ilmu", (Yogyakarta: Fakultas Filsafat UGM).

Djohar, Prof., 2007, Materi Perkuliahan Filsafat Ilmu, (Yogyakarta: PPS UNY).

Hardiman, 2003, Melampaui Positivisme dan Modernitas, (Yogyakarta: Kanisius).

Jujun S. Suriasumantri, 1984, Filsafat Ilmu, (Jakarta: Sinar Harapan).

, 1986, Ilmu dalam Perspektif Moral, Sosial, dan Politik: Sebuah Dialog tentang Dunia Keilmuan Dewasa Ini, (Jakarta: PT. Gramedia).

Koento Wibisono, 1985, Ilmu Filsafat dan Aktualitasnya dalam Pembangunan Nasional: Suatu Tinjauan dari Sudut Tradisi Pemikiran Barat, (Yogyakarta: Gadjah Mada University Press).

, 1996, Arti Perkembangan menurut Positivisme August Comte, cet 2, (Yogyakarta: Gadjah Mada University Press).

, 2005a, Pengertian tentang Filsafat, Hand Out, (Yogyakarta: Program Pascasarjana Filsafat UGM).

, 2005b, "Ilmu Pengetahuan, sebuah Sketsa umum mengenai Kelahiran dan Perkembangannya sebagai Pengantar untuk Memahami Filsafat Ilmu", dalam Koento Wibisono, Hubungan Filsafat, Ilmu Pengetahuan, dan Budaya, Hand Out, (Yogyakarta: Program Pascasarjana Filsafat UGM).

Kompas, 25 Mei 1981.

Magnis Suseno, 1992, Filsafat sebagai Ilmu Kritis, (Yogyakarta: Kanisius). 
Noeng Muhadjir, 2003, Filsafat Islam Telaah Fungsional, Suplemen Filsafat Ilmu edisi II, (Yogyakarta: Rake Sarasin).

Poespoprojo, 1986, “Aktualitas Filsafat Ilmu ke Arah Kemasakan Praktek dan Pengelolaan Ilmu”, dalam Jujun S. Suriasumantri, Ilmu dalam Perspektif Moral, Sosial, dan Politik, (Jakarta: Gramedia).

T. Jacob, 1988, Manusia, Ilmu dan Teknologi, Pergumulan Abadi dalam Perang dan Damai, (Yogyakarta: PT. Tiara Wacana).

, "Etika Ilmiah dan Pancasila", dalam Soeroso H.P., dkk., Pancasila sebagai Orientasi Pengembangan Ilmu, (Yogyakarta: Kedaulatan Rakyat).

Van Peursen, 1976, Strategi Kebudayaan, terj. Dick Hartoko, (Yogyakarta: Kanisius, \& BPK Gunung Mulia, Jakarta) 